\title{
Some Success Factors for the Communal Management of Knowledge
}

\begin{abstract}
:
Chris Kimble and Isabelle Bourdon

This paper explores the contribution of communal structures such as Communities of Practice (CoPs) on Intra-organizational Knowledge Management (KM). First, we look at intra organizational knowledge management and explore the role that information systems can play. We introduce the idea of "Systèmes d'Aide à la Gestion des Connaissances" SAGC (Systems to aid the Management of Knowledge) and then establish our theoretical foundations concerning communal KM, especially as it relates to the structural and functional characteristics of CoPs. The results of an exploratory qualitative survey involving Chief Knowledge Officers (CKOs) of large French businesses are presented which examine the contribution that communal structures such as CoPs can make to Intra-organizational KM. The results highlight some of 'success factors' for the communal management of knowledge. Two types of factors in particular appear to encourage the sharing of knowledge: those related to (1) the characteristics of a CoP (2) the organizational context. The work indicates that, perhaps contrary to what might be expected, many of the key success factors are the same 'management' issues that can found in almost any IS project while some of the issues that the literature indicates are important, appear to be less so in practice.
\end{abstract}

\section{Introduction}

The focus of this paper is principally on Intra-organizational Knowledge Management (KM) and the contribution that communal structures such as Communities of Practice (CoPs) can make to this. The concept of a firm based on knowledge views the management of organizational knowledge as the main source of competitive advantage, and knowledge sharing is a core activity in such enterprises. DeLong and Fahey (2000) see the creation of a culture that encourages positive attitudes to knowledge sharing as being one of the key factors behind successful Knowledge management initiatives.

Developments in Information Technology, coupled with increasing awareness of the importance of organizational knowledge, have led to the development of a variety of Information Systems (IS) that attempt to manage this knowledge. Notwithstanding the drive toward using IS to manage knowledge, there is also a recognition that most organizational knowledge remains firmly anchored in individuals (Hildreth \& Kimble, 2002), and consequently, the KM process is highly dependent on the behaviour of the employees within an organization. For example, Child and Shumate, (2007) see Knowledge Management Systems (KMS) as being systems where information is shared collectively; where members of the organization both draw upon a store of information and also contribute to its maintenance.

The resistance of certain groups or individuals frequently impedes the Intra-organizational knowledge sharing; this is why many organizations are now beginning to look at communitybased models, which, it is believed, will encourage the sharing of knowledge. Child and Shumate, (2007) also note that CoPs, where knowledge is continuously negotiated through processes of social interaction and networking, are likely to enhance knowledge sharing where a strategy of Communal Knowledge Management is being followed.

CoPs appear to be one of the most favoured organizational forms to encourage the sharing of organizational knowledge. Argote et al identified a set of emergent issues for the future of research on $\mathrm{KM}$. They highlight the "importance of social relations in understanding knowledge creation, retention and transfer" and "the fit between properties of knowledge and

C. Kimble and I. Bourdon. Some success factors for the communal management of knowledge. International Journal of Information Management, 28(6), 2008, pp. 461 - 467.

DOI: 10.1016/j.jijnomgt.2008.08.007 
properties of relationships in a social system" (Argote, McEvily, \& Reagans, 2003). They point to the need to shift our interest from single to multiple relations when dealing with the $\mathrm{KM}$ process. Such indications suggest that we should concentrate our research efforts on achieving a more complete understanding of key features of community-based organizations.

The rest of the paper is organized as follows; the literature of intra organizational knowledge management and the role that information systems can play is briefly reviewed. The idea of "Systèmes d'Aide à la Gestion des Connaissances" SAGC (Systems to aid the Management of Knowledge) is introduced and the theoretical foundations for our empirical investigation are introduced. The results of the exploratory qualitative study involving Chief Knowledge Officers (CKOs) of twelve large French businesses (industry, services and consulting) which sought to identify the factors influencing the success of community based approaches to intra-organizational KMS are then presented. The paper concludes with the observation that issues such as the role of Wenger's participation - reification duality (Wenger, 1998b) seem to be less important than expected while generic 'management" issues such as those that might be found in any IS project remain crucial.

\section{Towards the Communal Management of Intra-organizational Knowledge}

\subsection{Intra-organizational Knowledge Management}

There are many definitions of knowledge (Hildreth \& Kimble, 2002) however, most are specific to the context in which they are used. From the KM perspective, Davenport and Prusak (2000) observe:

"Knowledge is a fluid mix of framed experiences, values, contextual information and expert insight that provides a framework for evaluating and incorporating new experiences and information." (Davenport \& Prusak, 1998)

While Schreiber et al. (1999), from an engineering perspective, define knowledge as:

"... the whole body of data and information that people bring to bear to practical use in action, in order to carry out tasks and create new information." (Schreiber, et al., 1999)

Although both have a slightly different definition for knowledge, their focus is the same: knowledge is a resource that needs to be managed; Knowledge Management systems (KMS) are seen as a way to take advantage of opportunities for exchange and knowledge sharing.

Two main models of KMS have been identified in the literature: the index model and the social network model (Hansen, Nohria, \& Tierney, 1999).

- The index or integrative model corresponds to a codification approach to KM. This approach focuses on the codification and the storage of knowledge in order to facilitate its reuse through access to the codified data.

- $\quad$ The social network or interactive model corresponds to a customization approach to $\mathrm{KM}$. This approach focuses on the links between individuals for the exchange of knowledge.

In modern organizations, groups can emerge from of virtual communities that share technological networks and forms of IS that we term 'Systèmes d'Aide à la Gestion des Connaissances' (SAGC). Following Reix (2004) the use of this term is intended to

C. Kimble and I. Bourdon. Some success factors for the communal management of knowledge. International Journal of Information Management, 28(6), 2008, pp. 461 - 467.

DOI: 10.1016/j.jijnomgt.2008.08.007 
differentiate between the 'warehouse' approach to KM where knowledge is simply stored for later (re)use and the 'learning' model where the creation and use of knowledge is seen as the outcome of an on-going interaction between subject and world.

\subsection{Communal Structures and the Management of Knowledge}

The work of Goffee and Jones (2003) on organizational culture has provided some useful insights into the problem of a wiliness to share knowledge in an organization. They produced a simple model of organizational culture based on the notions of sociability and solidarity. Sociability is defined in terms of reciprocal relationships between people.

"Sociability is much as it sounds: a measure of friendliness among members of a community ... People do kind things for each other because they want to ... sociability flourishes among people who share similar ideas, values, personal histories, attitudes and interests" (Goffee \& Jones, 2003, p 24)

Solidarity of the other hand is defined in terms of relationships between individuals and the wider organization.

"In contrast top sociability, solidarity is based not so much in the heart but the mind. Solidaristic relationships are based on common tasks, mutual interests, and clearly understood shared goals that benefits all the involved parties, whether they personally like each other or not." (Goffee \& Jones, 2003, p 29)

Taken together, Goffee and Jones (2003) use these definitions to describe four different cultural orientations: (1) communal culture (high sociability, high solidarity), (2) networked culture (high sociability, low solidarity), (3) fragmented culture (low sociability, low solidarity), (4) mercenary culture (low sociability, high solidarity). It is the first of these cultural orientations that we are concerned with in this paper.

We have already noted that Child and Shumate, (2007) believe that CoPs are likely to enhance knowledge sharing where a strategy of communal KM is being followed. Lave and Wenger (Lave \& Wenger, 1991) first defined CoPs as:

"... a set of relations among persons, activity, and world, over time and in relation with other tangential and overlapping Communities of Practice" (Lave \& Wenger, 1991, p98)

To be a member of a CoP is about participation in an activity:

"Participation in an activity system about which participants share understandings concerning what they are doing and what that means for their lives and for their communities." (Lave \& Wenger, 1991, p 98)

Like Goffee and Jones description of communal culture, CoPs are groups of people that share common goals and participate in some shared activity, but are also united by social bonds forged through interactions within the community.

The literature on the $\mathrm{KM}$ puts the accent on the fact that the CoPs can encourage the management of knowledge and can constitute the organizational structures needed to support KM (Iverson \& McPhee, 2002). For example, CoPs have been used as the model for knowledge sharing in primary health care trusts (Gabbay \& le May, 2004) and even in the British Council (Venters \& Wood, 2007).

C. Kimble and I. Bourdon. Some success factors for the communal management of knowledge. International Journal of Information Management, 28(6), 2008, pp. 461 - 467.

DOI: 10.1016/j.jijnomgt.2008.08.007 


\subsection{The Structural and Functional Characteristics of CoPs}

In his book 'Communities of Practice: Learning, Meaning and Identity', Wenger provides a concise definition for the structure of a CoP that consists of just three interrelated terms: 'mutual engagement', 'joint enterprise' and 'shared repertoire' (Wenger, 1998b, pp 72 - 73).

\section{- $\quad$ Mutual Engagement}

Firstly, through participation in the community, members establish norms and build collaborative relationships; this is termed mutual engagement. These relationships are the ties that bind the members of the community together as a social entity.

- Joint Enterprise

Secondly, through their interactions, they create a shared understanding of what binds them together; this is termed the joint enterprise. The joint enterprise is (re)negotiated by its members and is sometimes referred to as the 'domain' of the community.

\section{- $\quad$ Shared Repertoire}

Finally, as part of its practice, the community produces a set of communal resources, which is termed their shared repertoire; this is used in the pursuit of their joint enterprise and can include both literal and symbolic meanings.

Wenger describes the 'engine' that animates this structure in terms of the inherent tensions that exist within and between for dualities. Wenger identifies four such dualities: participation-reification, designed-emergent, identification-negotiability and local-global.

\section{- $\quad$ Participation-Reification}

The Participation-Reification duality is concerned with meaning. Meaning is created through participation and active involvement in some practice. Reification is a way of making an abstract and concise representation of what is often a complex and frequently messy practice, thus making it easier to share within the community.

\section{- Designed-Emergent}

The Designed-Emergent duality focuses on time and captures the tension between pre-planned and emergent activities. Designers plan an activity designed to achieve a particular purpose however, activities can emerge through interaction in the community, which are unplanned and may be contrary to what the designers intended.

\section{- Identification-Negotiability}

The Identification-Negotiability duality is concerned with "how the power to define, adapt, or interpret the design is distributed" (Wenger, 1998b, p 235). This can include not only how an individual perceives themselves but also their right to contribute to and shape the direction of a community as a whole.

\section{- $\quad$ Local-Global}

The Local-Global duality concerns how one CoP relates to another. Wenger uses notions of boundary objects, brokerage (Wenger, 1998b, pp 106 - 108) and boundary encounters (Wenger, McDermott, \& Snyder, 2002, p 84) to explain how individuals can establish relationships with and learn from other communities.

\subsection{CoPs and the Management of Intra-organizational Knowledge}

In his book with McDermott and Snyder he "concentrates primarily on the ability of Communities of Practice to steward knowledge inside organizations" (Wenger, et al., 2002, p 219). Similarly, with Snyder and Biggs (2003) he sets out to "define communities of practice as a tool for cross-organizational collaboration" portraying CoPs as groups that "...

C. Kimble and I. Bourdon. Some success factors for the communal management of knowledge. International Journal of Information Management, 28(6), 2008, pp. 461 - 467.

DOI: 10.1016/j.jijnomgt.2008.08.007 
complement formal units to help organizations weave critical connections across formal groups and leverage knowledge for performance" (Snyder, et al., 2003, p 19).

CoPs are seen as groups that can spread out and cross the boundaries that exist inside an organization "Communities of Practice are not just places where local activities are organized, but also where the meaning of belonging to broader organizations is negotiated and experienced" (Wenger, 1996). CoPs become organizational structures that drive individuals, through their common interest, to share their knowledge and expertise.

As a brief introduction to the topic, we have summarized key points from a few of the works that deal with the contribution of CoPs to the management of Intra-organizational knowledge and Intra-organizational knowledge sharing in Table 1 below.

\begin{tabular}{|l|l|}
\hline Authors & Foundations \\
\hline (Brown \& Duguid, 1991) & $\begin{array}{l}\text { The flows of knowledge are better through networks of } \\
\text { individuals who share the same interests in their work. }\end{array}$ \\
\hline (Dyer \& Nobeoka, 2000) & $\begin{array}{l}\text { The relationships within a CoP, characterized as 'mutual } \\
\text { causality', are both a cause and a consequence of the } \\
\text { process of learning and sharing of knowledge. }\end{array}$ \\
\hline (Hall, 2001) & $\begin{array}{l}\text { The environments that encourage CoPs are also more } \\
\text { favourable to the activities of sharing knowledge. }\end{array}$ \\
\hline $\begin{array}{l}\text { (Hildreth \& Kimble, 2002), } \\
\text { (Kimble \& Hildreth, 2005) }\end{array}$ & $\begin{array}{l}\text { The role of CoPs in knowledge sharing: notably the role of } \\
\text { shared artefacts, such as a SAGC, and the role of face-to- } \\
\text { face communication. }\end{array}$ \\
\hline (Jarvenpaa \& Staples, 2000) & $\begin{array}{l}\text { When individuals are encouraged to share their knowledge } \\
\text { within a CoP, the cultural barriers to knowledge transfer } \\
\text { weaken. }\end{array}$ \\
\hline (Lefebvre et al., 2004) & $\begin{array}{l}\text { The conditions for the spontaneous emergence of a CoP } \\
\text { based on knowledge sharing can exist inside a research and } \\
\text { development unit. }\end{array}$ \\
\hline (McLure Wasko \& Faraj, \\
2000) & $\begin{array}{l}\text { In a CoP, the exchange of knowledge is motivated by a moral } \\
\text { obligation or interest in the community rather than by } \\
\text { personal interest. }\end{array}$ \\
\hline (O'Dell \& Grayson, 1998) & $\begin{array}{l}\text { The lack of contact, relationships and common outlook } \\
\text { between individuals is a manifest barrier to the transfer of the } \\
\text { knowledge. }\end{array}$ \\
\hline (Pan \& Leidner, 2003) & $\begin{array}{l}\text { The importance of CoPs in the management of knowledge } \\
\text { and the role that IT can play in sustaining knowledge sharing } \\
\text { inside and between CoPs. }\end{array}$ \\
\hline (Vaast, 2002) & $\begin{array}{l}\text { The principal features of a CoP can be sustained by the use } \\
\text { of an intranet. The feeling of belonging to a CoP is very } \\
\text { important. }\end{array}$ \\
\hline
\end{tabular}

Table 1: The potential contributions of CoPs to KM

Having established our theoretical foundations, we now wish to explore, in a more empirical manner, the factors that are perceived by the communities 'on the ground' to be favourable to the sharing of knowledge, particularly when using SAGCs.

\section{An Exploratory Qualitative Survey}

Previous studies (Bourdon, Vitari, \& Ravarini, 2003; Bourdon, Vitari, Moro, \& Ravarini, 2004) have developed a research model based on the acceptance of KMS that indicates that the

C. Kimble and I. Bourdon. Some success factors for the communal management of knowledge. International Journal of Information Management, 28(6), 2008, pp. 461 - 467.

DOI: 10.1016/j.ijinfomgt.2008.08.007 
acceptance of KMS is determined, in addition to the classical constructs of the technology acceptance model (TAM), by a few organizational factors. In order to identify the factors of CoPs perceived to be favourable to the sharing of knowledge via communal KMS, we analysed the views of the people who were actually in charge of such systems.

\subsection{The Methodology}

The methodology for this work is broadly that of qualitative study (Cassell \& Symon, 2004); its goal was to examine a series of propositions concerning the factors that influence the success of communal KM in Intra-organizational settings. The works of Goffee and Jones (2003) on the notion of communality, Reix (2004) on Information Systems and KM together with the work of Wenger (1998b; 2002) on CoPs, provided both the initial propositions and a framework within which to analyse the data.

The study was a part of a larger research $\mathrm{PhD}$ project concerned with exploring success factor of KMS (Bourdon, 2004). The study consisted of fourteen semi-structured qualitative research interviews with a set of CKOs from twelve large French companies. The interviews enabled us to explore participants' experiences of communal KMS within their own work contexts, while also enabling the interviewer to play a role in guiding the direction of the discussion.

\begin{tabular}{|c|c|c|c|c|c|}
\hline $\begin{array}{c}\text { Company } \\
\text { Name }\end{array}$ & $\begin{array}{l}\text { Enterprise } \\
\text { Activity }\end{array}$ & $\begin{array}{c}\text { Enterprise } \\
\text { description }\end{array}$ & $\begin{array}{c}\text { Communal KMS } \\
\text { description }\end{array}$ & Job title & $\begin{array}{c}\text { Interview } \\
\text { length }\end{array}$ \\
\hline B & $\begin{array}{l}\text { Conformity } \\
\text { evaluation }\end{array}$ & $\begin{array}{l}25,000 \\
\text { employees in } \\
140 \\
\text { countries, } \\
\text { turnover } \\
€ 1.6 b(2005)\end{array}$ & $\begin{array}{l}\text { Intranet KMS with } \\
\text { collaborative } \\
\text { functions - } 80 \text { CoPs } \\
\text { ( } 30 \text { international) }\end{array}$ & $\begin{array}{l}\text { Director of } \\
\text { KM }\end{array}$ & $45 \mathrm{~min}$ \\
\hline C & $\begin{array}{l}\text { Consulting, } \\
\text { technology and } \\
\text { outsourcing } \\
\text { services }\end{array}$ & $\begin{array}{l}52,700 \\
\text { people } \\
\text { worldwide } \\
€ 7.0 \mathrm{~b} \text { global } \\
\text { revenues }\end{array}$ & $\begin{array}{l}\text { CKMS "GALAXY", } \\
\text { knowledge server } \\
\text { repository of } \\
\text { technical } \\
\text { information }\end{array}$ & CKO & $1 \mathrm{hr}$ \\
\hline D & $\begin{array}{l}\text { Consultancy } \\
\text { firm in network } \\
\text { and systems } \\
\text { infrastructures }\end{array}$ & $\begin{array}{l}\text { Turnover } \\
€ 400 \mathrm{~m} \\
(2007) \\
\text { Workforce } \\
\text { more than } \\
4000 \\
\end{array}$ & $\begin{array}{l}\text { Knowledge portal, } \\
\text { expert repertory } \\
\text { and Lotus Notes, } \\
10 \text { knowledge } \\
\text { communities }\end{array}$ & CKO & $45 \mathrm{~min}$ \\
\hline$E$ & $\begin{array}{l}\text { Energy and } \\
\text { gas industry }\end{array}$ & $\begin{array}{l}\text { Worldwide } \\
\text { workforce } \\
158,640 \\
€ 4.7 \mathrm{~b} \text { net } \\
\text { income in } \\
2007\end{array}$ & $\begin{array}{l}\text { DIADEME : a } \\
\text { collective } \\
\text { knowledge } \\
\text { management } \\
\text { system (400 } \\
\text { people) }\end{array}$ & CKO & $1 \mathrm{hr}$ \\
\hline ES & $\begin{array}{l}\text { Corrective } \\
\text { lenses }\end{array}$ & $\begin{array}{l}2000 \\
\text { employees } \\
€ 2,908 \\
\text { turnover }\end{array}$ & $\begin{array}{l}\text { GEODE CKMS, } \\
\text { used for R\&D, } 10 \\
\text { CoPs for } 400 \\
\text { people }\end{array}$ & CKO & $1.5 \mathrm{hrs}$ \\
\hline $\mathrm{M}$ & $\begin{array}{l}\text { Government } \\
\text { ministry: } \\
\text { transport }\end{array}$ & $\begin{array}{l}\text { Budget, in } \\
\text { order of } \\
€ 20 \mathrm{~m}\end{array}$ & $\begin{array}{l}\text { Communal } \\
\text { structure non } \\
\text { institutionalised }\end{array}$ & CKO & $1 \mathrm{hr}$ \\
\hline
\end{tabular}

C. Kimble and I. Bourdon. Some success factors for the communal management of knowledge. International Journal of Information Management, 28(6), 2008, pp. 461 - 467.

DOI: 10.1016/j.jijnomgt.2008.08.007 


\begin{tabular}{|c|c|c|c|c|c|}
\hline $\begin{array}{l}\text { Company } \\
\text { Name }\end{array}$ & $\begin{array}{c}\text { Enterprise } \\
\text { Activity }\end{array}$ & $\begin{array}{c}\text { Enterprise } \\
\text { description }\end{array}$ & $\begin{array}{c}\text { Communal KMS } \\
\text { description }\end{array}$ & Job title & $\begin{array}{c}\text { Interview } \\
\text { length }\end{array}$ \\
\hline$R$ & Automobile & $\begin{array}{l}€ 40.68 \mathrm{~m} \\
130,179 \\
\text { employees }\end{array}$ & $\begin{array}{l}\text { MEREX method for } \\
\text { capitalizing } \\
\text { experiences }\end{array}$ & $\begin{array}{l}\text { Head of the } \\
\text { SAGC office }\end{array}$ & $1 \mathrm{hr}$ \\
\hline S & Pharmaceutical & $\begin{array}{l}100,000 \\
\text { employees } \\
\text { worldwide }\end{array}$ & KMS on quality & $\begin{array}{l}\text { Head of the } \\
\text { SAGC office }\end{array}$ & $1 \mathrm{hr}$ \\
\hline Sc & $\begin{array}{l}\text { Oil-field- } \\
\text { services } \\
\text { company }\end{array}$ & $\begin{array}{l}\$ 23.28 b \\
\text { revenue, } \\
84,000 \\
\text { employees in } \\
80 \text { countries }\end{array}$ & $\begin{array}{l}\text { Eureka CKMS : } 23 \\
\text { CoPs, with about } \\
140 \text { special-interest } \\
\text { subgroups }\end{array}$ & $\begin{array}{l}\text { Community } \\
\text { leader }\end{array}$ & $1 \mathrm{hr}$ \\
\hline ScE & $\begin{array}{l}\text { Automation } \\
\text { and electricity } \\
\text { management }\end{array}$ & $\begin{array}{l}70,000 \\
\text { employees, } \\
€ 8.78 \mathrm{~m} \\
\text { turnover in } \\
2003\end{array}$ & $\begin{array}{l}70 \text { Communities, } \\
\text { Knowledge Base }\end{array}$ & $\mathrm{ClO}$ & $1 \mathrm{hr}$ \\
\hline $\mathrm{T}$ & $\begin{array}{l}\text { Systems for } \\
\text { Aerospace, } \\
\text { Defence and } \\
\text { Security }\end{array}$ & $\begin{array}{l}68,000 \\
\text { employees, } \\
€ 12.3 \mathrm{~b} \\
\text { annual } \\
\text { revenues }\end{array}$ & $\begin{array}{l}\text { Websphere Portal } \\
\text { infrastructure for } \\
\text { R\&D (20.000 } \\
\text { people) }\end{array}$ & $\begin{array}{l}\text { Head of the } \\
\text { intranet } \\
\text { office }\end{array}$ & $1.5 \mathrm{hrs}$ \\
\hline U & steel company & $\begin{array}{l}320,000 \\
\text { employees, } \\
\text { US } \$ 105.2 b\end{array}$ & $\begin{array}{l}\text { Sachem system of } \\
\text { knowledge } \\
\text { capitalization }\end{array}$ & $\begin{array}{l}\text { Head of the } \\
\text { intranet } \\
\text { office }\end{array}$ & $1 \mathrm{hr}$ \\
\hline
\end{tabular}

Table 2: survey sample

The survey was completed in two stages. The first interview consisted of themes and subthemes to discuss in the interview; this was drafted beforehand based on a reading of the literature. The second stage consisted of more focused semi-directive interviews based on an amended guide, which enabled us to check on and delineate the factors from the previous interview.

The interview data was analysed, following (Berelson, 1952), by using inductive content analysis based on open coding, the fracturing of themes and sub-themes across the interviews and the emergence of recurring links. We defined our units of analysis as sentences, parts of sentences or groups of sentences, and then grouped them based on thematic content.

\subsection{Results}

We now present the key results of our qualitative survey into the factors that seem to influence the success of communal approaches KM. The survey highlights two types of factors present in community-based organizations that appear to encourage the sharing of knowledge: (1) Factors related to the characteristics of a CoP (2) Factors related to the organizational context. Due to constraints of space, we will simply presented a few key examples of 'units of meaning' using illustrative quotes.

\subsubsection{Factors related to the characteristics of a CoP}

The thematic analysis of the interviews pointed to some underlying features of CoPs that were perceived to be important for knowledge sharing via SAGCs.

C. Kimble and I. Bourdon. Some success factors for the communal management of knowledge. International Journal of Information Management, 28(6), 2008, pp. 461 - 467.

DOI: 10.1016/j.jijnomgt.2008.08.007 


\begin{tabular}{|l|}
\hline The pre-existence of a community \\
\hline An understanding of the community \\
\hline The formal structure of the community \\
\hline The size of the community \\
\hline The level of cooperation in the community \\
\hline The vitality of the exchanges in the community \\
\hline The presence of a shared repertoire within the community \\
\hline The existence of clear positive benefits \\
\hline The existence of a standard or indicator for the community \\
\hline The quality of the exchanges \\
\hline Trust within the community \\
\hline The time allocated to community activities \\
\hline The existence of rituals in the community \\
\hline
\end{tabular}

Table 3: Factors related to the characteristics of the CoPs

The pre-existence of a community. It appeared that the presence of a community, or the perception of its pre-existence, was an element that managers considered a key factor in the success of this form of KM. For example:

"[...] in general when a network of people exists, it facilitates the technology [of the SAGC]; things go rather better [...] then when one injects the technology [...] when there are no pre-existent networks, it is true, the exercise is a lot more difficult"

An understanding of the community. A deep understanding the focus of the community, the what, the how, its boundary, its composition and its goals was seen as an important element. For example, an interviewee thinks:

"[...] one needs [...] to identify those communities; to know what should exist [...] after, [the community has bedded in] it needs to exist for the company, not locally in a bubble"

The formal structure of the community. Setting up a formal structure for the underlying $\mathrm{CoP}$ in relation to the SAGC is also an important element in the sharing of knowledge. For example, the creation of the role of animateur or the leader of the community was seen as a key factor for the success of this approach:

"[every community] has one or two leaders [...] who are nominees elected by the members of the community, and who belong to the community"

The size of the community. The theme of the 'critical mass' of the community was considered crucial by the interviewees, for example:

"[...] the $X$ community included 800 people and it didn't work at all, there was no activity, it had died [it] was too large, therefore it divided in 13 different communities"

The level of cooperation in the community. Another element is, of course, connected to the perceived level of cooperation. For example:

C. Kimble and I. Bourdon. Some success factors for the communal management of knowledge. International Journal of Information Management, 28(6), 2008, pp. 461 - 467.

DOI: 10.1016/j.ijinfomgt.2008.08.007 
"[...] it is necessary to generate patterns of interactions and cooperation in communities where people are placed; but one cannot master all of these networks; on the contrary, one must act from within"

The vitality of the exchanges in the community. This theme is also close the notion of the vitality of the exchanges within the community, for example:

"[...] what it is necessary to get [the CoP going] is a bandwagon effect, because, in a community of experts, there is [...] 30\% of the community that will go there, then, there are the others that are baffled because they don't go there"

The presence of a shared repertoire within the community. The creation of a shared repertoire within the community is indispensable in terms of vision, common language, terminology, norms, principles, securities or beliefs. For example:

"[...] the essential first, it is to become aware that behind the obvious differences, there are the common goals, [which allow the] formalizing of knowledge and experiences"

The existence of clear positive benefits. The perception of the benefits of exchange within the community is essential. From an individual standpoint, a KMS officer pointed out that:

"[...] usually, members of the community go for it because it adds something for their own work"

Regarding the perceived organizational consequences, another said:

"We now work on the hypothesis that this kind of system can help every user in the community to gain an hour a week"

The existence of a standard or indicator for the community. The perception of the performance and results of the CoP in terms of a standard indicator is a critical characteristic. For example:

"To understand this success, we have accumulated stories, there have been 15 success stories across all communities, that say why it was a success, and in the end, [the community] was voted a success based on all the stories"

The quality of the exchanges. The perception of the quality of the exchanges within the community is considered another factor that encourages sharing. So an interviewee indicates:

"In the system [...] what is difficult to measure, it is the relevance of the answer, it would be necessary to put the questioner's feedback in place such as - this answer helped me indeed, it save me so much time"

Trust within the community. Trust within the CoP is perceived to be a factor encouraging the sharing of knowledge:

"[...] one is going to share, if one knows people, if one respects them, if one has trust in them and if it gives one pleasure [to share] with them in a protected space"

C. Kimble and I. Bourdon. Some success factors for the communal management of knowledge. International Journal of Information Management, 28(6), 2008, pp. 461 - 467.

DOI: 10.1016/j.jijnfomgt.2008.08.007 
The time allocated to community activities. Interviewees felt that time restrictions were another element that could influence individual participation to community. For example:

"[...] devoting time to building the community is no easy matter; time restrictions, which were not so common before, are now a major issue, [...]. Even when people are willing to do it, it's not necessarily their main work"

The existence of rituals in the community. Finally, the setting-up of key events that are often cited as success factors, for example:

"[in the domain of the quality], the quality community exists, there is a big meeting twice a year with good grub for the 150 people in charge of the quality that lasts all day [...] it is a festive event and people want to come and [...] after they met and communicated, there were some further exchanges"

\subsubsection{Factors related to the organizational context}

Secondly, we present the main topics raised by the interviewees with regard to the organizational context.

\begin{tabular}{|l|}
\hline The support of management \\
\hline The provision of resources for the community \\
\hline An organizational structure that facilitates collaboration \\
\hline An organizational culture of sharing \\
\hline Training in the use of supporting technologies \\
\hline Appropriate systems of evaluation and incentives \\
\hline The support of HRM \\
\hline
\end{tabular}

Table 4: Factors related to the characteristics of the organizational context

Different interviewees insisted, repeatedly, that certain aspects of the organization itself acted as inhibitory or facilitating factors for knowledge sharing via SAGCs. The following quotations provide a few examples of such comments.

The support of management. Content analysis of the interviews revealed that the influence of managers and senior executives was a recurrent theme. For example, regarding the influence of managers:

"[...] management has to be really involved in this approach, because locally it can have an effect on contributors in the field"

Likewise, regarding the influence of senior executives, another officer felt that:

"[...] one condition for it to work is that it is a priority for the company, [...] directors have to be visibly committed"

The provision of resources for the community. The support for the community is also demonstrated by the provision of resources for the community: one interviewee commented:

"[...] it worked, because people, experts on the subject, people with community recognition, guys of 55 reputed to be the best in the field, were assigned to the project to work on the aspects of building expertise"

C. Kimble and I. Bourdon. Some success factors for the communal management of knowledge. International Journal of Information Management, 28(6), 2008, pp. 461 - 467.

DOI: 10.1016/j.jijnfomgt.2008.08.007 
An organizational structure that facilitates collaboration. The organizational structure can enable or inhibit the sharing of knowledge. In particular, it affects the possibility for knowledge transfer across organizational units and/or hierarchical levels. Thus, for example:

"[...] as long as company organization is vertical, with departments and divisions, even if you have matrices, as long as you stick to this logic, you create compartments that are responsible for obstructing outreach networks"

An organizational culture of sharing. A culture of sharing is considered an indispensable element for sustaining communities and the systems dedicated to them. Organizational culture produces a system of rules or norms that drive the individuals' behaviours. For example:

"[...] it's the cultural side that is the hardest to overcome [...] getting people into sharing mode, that's the hardest part"

Similarly, another officer felt that:

"[...] we have encountered some fairly complicated problems, not technical ones, but to do with culture and management"

Support in the use of supporting technologies. Training and communication for the members of communities in the use of supporting technologies are seen as factors in the success of community-based KMS. Thus:

"[...] communication has not been made a priority objective [...] aspects of the management and capitalization of knowledge requires a lot of communication in order to explain to people what it is and what it contains. We must inform people about what exists"

Appropriate systems of evaluation and incentives. Finally, according to those interviewed the evaluation systems and incentive schemes in place can encourage or discourage the sharing via SAGCs. One interviewee said:

"If I were assessed and paid on the basis of my contribution to knowledgesharing and effective feedback, then I'd join the system"

Another pointed out:

"[...] today our managers are not recruited on those criteria [...] the way people are selected and sent up the career ladder is at the heart of capitalising on experience"

Some companies in the sample had introduced incentive schemes to encourage potential SAGC contributors. One officer said:

"[...] if I were assessed and paid on the basis of my contribution to knowledgesharing and effective feedback, then I'd join the system"

Another pointed out:

"[...] today our managers are not recruited on those criteria [...] the way people are selected and sent up the career ladder is at the heart of experience capitalization"

C. Kimble and I. Bourdon. Some success factors for the communal management of knowledge. International Journal of Information Management, 28(6), 2008, pp. 461 - 467.

DOI: 10.1016/j.jijnomgt.2008.08.007 
The support of HRM. According to the people we questioned, the support of the HRM department with regard to the recognition and the processes of evaluation were essential. For example:

"[...] the key is to have a reason to give, for the recognition, for value, because if someone is motivated to do so, then using the tools is not the hardest part"

\section{Discussions and Conclusions}

From the theoretical viewpoint, the potential contribution of CoPs to KM seems clear (see Table 1 for examples of this). Additionally, the works of Wenger (Wenger, 1998b, 1998a, 2000; Wenger, et al., 2002) readily lend themselves to the identification of various 'factors' that ought to influence the success with which CoPs are formed and the way in which they interact with a 'host' organization (Bourdon, et al., 2003). In contrast to quantitative approaches (Bourdon, et al., 2004), the aim of this study was to gain an insight into what practitioners of KM felt were the factors that most influenced the success of CoPs based approaches to KM.

Unsurprisingly, the survey confirmed the importance of CoPs for KM and showed that human factors were an essential component in the development of SAGCs. Of more interest was the emphasis that the interviewees put on the various elements of what we have called the communal model of KM. For example, Wenger (1998b) presented CoPs as containing a number of inherent tensions, which he termed dualities. The academic literature on KM and CoPs (Hildreth \& Kimble, 2002; Kimble \& Hildreth, 2005) tends to place the participation reification duality at the centre when dealing with CoPs as a mechanism for Managing Knowledge. The results of the survey however seem to indicate that other aspects, such as those related to organizational structure and, more broadly, 'management' issues, are of more importance.

Similarly, it is interesting to note that, in relation to SAGCs, many of the issues that were raised were 'generic' issues of the type that have seen before in relation to other forms of IS (Kimble \& McLoughlin, 1995). During the late 1990s and in the early years of this millennium, there was a tendency to see KMS as some new and exotic form of Information System. Since then it has become clear that KBS face many of the same issues as other forms of IS and, in contrast to findings on CoPs and KM, here the survey seems to back the literature.

So, what of the future? The different features of the communal models of KM identified in this research could constitute the elements of a system of evaluation for CoPs in KM. Further quantitative analysis of these characteristics in one or several other communities would be an interesting topic for research. Another area that this work appears to highlight is the tensions between the need to manage KM within existing organizational structures and the need for CoPs to grow and develop in their own way. One of the potentially most interesting aspects of this work is the indication it contains that the role of some of the other dualities identified by Wenger, such as the designed-emergent duality, may also play a role in Knowledge Management.

C. Kimble and I. Bourdon. Some success factors for the communal management of knowledge. International Journal of Information Management, 28(6), 2008, pp. 461 - 467.

DOI: 10.1016/j.jijnomgt.2008.08.007 


\section{References}

Argote, L., McEvily, B., \& Reagans, R. (2003). Managing Knowledge in Organizations: An Integrative Framework and Review of Emerging Themes. Management science, 49, 571582.

Berelson, B. (1952). Content Analysis in Communication Research. New York.

Bourdon, I. (2004). Les facteurs de succès des systèmes intégratifs d'aide à la gestion des connaissances. Université Montpellier II, Montpellier.

Bourdon, I., Vitari, C., Moro, J., \& Ravarini, A. (2004). The key success factors affecting KMS adoption: quantitative results. In Colloque de l'AIM (pp. 8). Evry, France.

Bourdon, I., Vitari, C., \& Ravarini, A. (2003). Les facteurs clés de succès des Systèmes de Gestion des Connaissances : proposition d'un modèle explicatif. In Colloque AIM (VIII ed.). Grenoble (France).

Cassell, C., \& Symon, G. (2004). Essential guide to qualitative methods in organizational research. London: Sage.

Child, J. T., \& Shumate, M. (2007). The Impact of Communal Knowledge Repositories and People-Based Knowledge Management on Perceptions of Team Effectiveness. Management Communication Quarterly, 21, 29-54.

Davenport, T. H., \& Prusak, L. (1998). Working knowledge: how organizations manage what they know. Boston, MA: Harvard Business School Press.

DeLong, D. W., \& Fahey, L. (2000). Diagnosing cultural barriers to knowledge management. Academy of Management Executive, 14, 113 - 127.

Gabbay, J., \& le May, A. (2004). Evidence based guidelines or collectively constructed mindlines? An ethnographic study of knowledge management in primary care. British Medical Journal, 329.

Goffee, R., \& Jones, G. (2003). The Character of a Corporation: How Your Company's Culture Can Make or Break Your Business: Profile Business Publications.

Hansen, M. T., Nohria, N., \& Tierney, T. (1999). What's Your Strategy for Managing Knowledge? Harvard Business Review, 77, 106-116.

Hildreth, P., \& Kimble, C. (2002). The duality of knowledge. Information Research, 8.

Iverson, J. O., \& McPhee, R. D. (2002). Knowledge Management in Communities of Practice: Being True to the Communicative Character of Knowledge. Management Communication Quarterly, 16, 259-266.

Kimble, C., \& Hildreth, P. (2005). Dualities, distributed communities of practice and knowledge management. Journal of Knowledge Management, 9, 102 - 113.

Kimble, C., \& McLoughlin, K. (1995). Computer Based Information Systems and Managers Work. New Technology, Work and Employment, 10, 56 - 67.

Lave, J., \& Wenger, E. (1991). Situated Learning: Legitimate Peripheral Participation. Cambridge: Cambridge University Press.

Reix, R. (2004). Systèmes d'information et management des organisations (5e édition ed.). Paris: Vuibert.

Schreiber, G., Akkermans, H., Anjewierden, A., de Hoog, R., Shadbolt, N., de Velde, W. V., \& Wielinga, B. (1999). Knowledge Engineering and Management: The CommonKADS Methodology. Massachusetts: MIT Press.

C. Kimble and I. Bourdon. Some success factors for the communal management of knowledge. International Journal of Information Management, 28(6), 2008, pp. 461 - 467.

DOI: 10.1016/j.jijinfomgt.2008.08.007 
Snyder, W. M., Wenger, E., \& Briggs, X. d. S. (2003). Communities of Practice in Government: Leveraging Knowledge for Performance. The Public Manager, 32, 17 - 21.

Venters, W., \& Wood, B. (2007). Degenerative structures that inhibit the emergence of communities of practice: a case study of knowledge management in the British Council. Information Systems Journal, 17, 349-368.

Wenger, E. (1996). Communities of Practice: The Social Fabric of a Learning Organization. Healthcare Forum Journal, 39, 20 - 24.

Wenger, E. (1998a). Communities of Practice: Learning as a Social System. Systems Thinker, 9.

Wenger, E. (1998b). Communities of Practice: Learning, Meaning, and Identity. New York: Cambridge University Press.

Wenger, E. (2000). Communities of Practice and Social Learning Systems. Organization, 7, $225-246$.

Wenger, E., McDermott, R. A., \& Snyder, W. (2002). Cultivating communities of practice : a guide to managing knowledge. Boston: Harvard Business School Press.

C. Kimble and I. Bourdon. Some success factors for the communal management of knowledge. International Journal of Information Management, 28(6), 2008, pp. 461 - 467.

DOI: 10.1016/j.jijnomgt.2008.08.007 